\title{
WILAYAH CAKUPAN PELAYANAN PEMBELI DI PASAR BANDAR BUAT KECAMATAN LUBUK KILANGAN KOTA PADANG
}

\author{
Nurul Qamilah ${ }^{1}$, Agel Vidian Krama ${ }^{2}$ \\ Institut Teknologi Sumatera ${ }^{1,2}$ \\ nurul.qamilah@gt.itera.ac.id ${ }^{1}$
}

\begin{abstract}
ABSTRAK
Penelitian ini bertujuan untuk memperoleh gambaran wilayah cakupan pelayanan pengunjung Pasar Bandar Buat Kecamatan Lubuk Kilangan Kota Padang dan seberapa besar pengaruh dari faktor-faktor penarik seperti: aksesibilitas, dan jarak, kualitas, harga, kelengkapan serta jenis barang. Jenis penelitian ini adalah Penelitian deskriptif dengan memadukan pendekatan kualitatif dan kuantitatif, sedangkan pendekatan yang dilakukan dalam pengambilan sampel adalah dengan teknik accsidental. Hasil penelitian menunjukkan bahwa: (1) wilayah cakupan pelayanan pengunjung khususnya pembeli di Pasar Bandar Buat tersebar pada sebelas kelurahan, dengan tujuh kelurahan yang terdapat Kecamatan Lubuk Kilangan, yaitu Kelurahan Tarantang, Kelurahan Beringin, Kelurahan Indarung, Kelurahan Padang Besi, Kelurahan Koto Lalang, Kelurahan Bandar Buat, Kelurahan Batu Gadang dan empat kelurahan lainnya dari dua kecamatan berbeda yaitu Kelurahan Piai Tangah, Kelurahan Limau Manis, Kelurahan Binuang Kampung Dalam yang terdapat di Kecamatan Pauh, dan Kelurahan Kuranji di Kecamatan Kuranji,. (2) faktor-faktor yang mempengaruhi pembeli untuk datang berbelanja ke Pasar Bandar Buat adalah Aksesibilitas dengan persentase sebesar 17\%, Jenis Barang dengan persentase sebesar $18 \%$, Kualitas Barang dengan persentase sebesar 23\%, Kelengkapan Barang dengan persentase sebesar 22\%, dan Harga Barang dengan persentase sebesar 20\%, faktor penarik yang menjadi pilihan utama pengunjung yaitu faktor kualitas barang dengan persentase sebesar 23\%. Kesimpulan terdapat tuhuh keluarahan sebagai Wilayah Cakupan Pelayanan Pasar Bandar Buat dan ada beberapa faktor yang mempengaruhi tingkat berbelanja masyakarat ke Pasar Bandar Buat seperti aksesibilitas dan jarak, jenis barang, kelengkapan barang, kualitas barang dan harga
\end{abstract}

Kata Kunci : Pasar, Faktor penarik, Wilayah Cakupan 


\section{ABSTRACT}

This study aims to obtain a description of the coverage area of visitor services Bandar Bandar Buat Kecamatan Lubuk Kilangan Kota Padang and how much influence of pull factors such as: accessibility, and distance, quality, price, completeness and type of goods. The type of this research is descriptive research by combining qualitative and quantitative approach, while approach taken in sampling is by accidental technique. The result of the research shows that: (1) The area of service coverage of visitors, especially buyers at Bandar Buat Market is spread in eleven urban villages, with seven sub-districts of Lubuk Kilangan, Tarantang, Beringin, Indarung, Padang Besi, Koto Lalang, Bandar Buat Village, Village of Batu Gadang and four other villages of the two districts different that Piai Tangah village, Village of Limau Manis, Binuang Kampung Dalam village contained in District Pauh, and village in the district Kuranji,. Factors influencing buyers to come shopping to Bandar Buat Market are 17\% Accessibility by percentage, Goods type with percentage of 18\%, Quality of Goods with percentage of 23\%, Completed Goods with percentage of 22\%, and Goods Price by percentage of 20\%, the pull factor that became the main choice of visitors is the factor of quality of goods with a percentage of $23 \%$. The conclusion is that there is an outline as the coverage area of Bandar Buat Market Services and there are several factors that influence the level of community shopping at Bandar Buat Market such as accessibility and distance, type of goods, completeness of goods, quality of goods and prices

Keywords: Market, pull factor, the coverage area

\section{PENDAHULUAN}

Perkembangan suatu wilayah
tidak terlepas dari aktivitas
perekonomian serta pertumbuhan penduduk yang ada di wilayah tersebut. Perkembangan pada sektor perekonomian secara spesifik ditentukan oleh dinamika sistem perdagangan yang ada pada suatu wilayah dan juga daerah sekitarnya. Salah satu sarana perdagangan adalah pasar, baik pasar tradisional maupun pasar modern. Menurut Umar (2003) pasar pada dasarnya dapat diartikan sebagai tempat pertemuan antara penjual dan pembeli atau kekuatankekuatan permintaan dan penawaran yang saling bertemu untuk membentuk suatu harga.

Pasar tradisional menurut $\mathrm{Nia}$ (2010) merupakan tempat bertemunya penjual dan pembeli serta ditandai dengan adanya transaksi penjual pembeli secara langsung dan biasanya ada proses tawar-menawar, bangunan biasanya terdiri dari kios-kios atau gerai, los dan dasaran terbuka yang dibuka oleh penjual maupun suatu pengelola pasar. Kebanyakan menjual kebutuhan sehari-hari seperti bahan-bahan makanan berupa ikan, buah, sayursayuran, telur, daging, kain, pakaian barang elektronik, jasa dan lain-lain. Selain itu, ada pula yang menjual kue- 
kue dan barang-barang lainnya. Pasar seperti ini masih banyak ditemukan di Indonesia, dan umumnya terletak dekat kawasan perumahan agar memudahkan pembeli untuk mencapai pasar.

Pasar Bandar Buat merupakan salah satu pasar tradisional yang terletak di Kecamatan Lubuk Kilangan Kota Padang. Pasar ini merupakan satusatunya pasar yang dikelola oleh pemerintah yang terdapat di Kecamatan tersebut. Meskipun bukan satu-satunya pasar yang ada di wilayah tersebut, karena pada Kecamatan Lubuk Kilangan terdapat tiga buah pasar yakni pasar Indarung, pasar Gaung dan Pasar Bandar Buat sendiri yang terletak di Kelurahan Bandar Buat tepatnya. Pasar Gaung dan pasar Indarung merupakan pasar yang dikelola oleh nonpemerintah, guna menunjang pasar Bandar Buat dalam pemenuhan kebutuhan masyarakat di wilayah tersebut. Untuk lebih jelasnya mengenai lokasi penelitian, dapat dilihat melalui peta di bawah ini.

Keberadaan pasar ini sangat membantu masyarakat dalam pemenuhan kebutuhan sehari-hari menyangkut masalah perekonomian. Pasar Bandar Buat merupakan satu dari tujuh belas pasar yang terdapat di Kota Padang, baik yang dikelola oleh pemerintah ataupun non-pemerintah. Pasar tradisional yang ada di Kota Padang tersebar di sebelas Kecamatan yang ada di Kota Padang.

Pasar Bandar Buat merupakan
salah satu pasar tradisional yang melayani masyarakat pengunjung pasar di Kecamatan Lubuk Kilangan Kota Padang. Keberadaan pasar ini sangat penting sekali bagi masyarakat Lubuk Kilangan yang tersebar ke dalam tujuh Kelurahan. Pasar ini memiliki hari pasar khusus yakni pada hari Selasa dan Sabtu yang dikenal dengan istilah "hari balai". Dari segi pembangunannya pasar Bandar Buat dibangun pada tahun 1981/1982 sehingga keberadaan pasar ini sudah tergolong tua dari pasar lainnya.

Pasar Bandar Buat terletak di salah satu kelurahan yang terdapat di Kecamatan Lubuk Kilangan yaitu tepatnya di Kelurahan Bandar Buat. Kelurahan lain yang terdapat di Kecamatan Lubuk Kilangan yakni, Kelurahan Tarantang, Kelurahan Beringin, Kelurahan Batu Gadang, Kelurahan Indarung, Kelurahan Padang Besi, dan Kelurahan Koto Lalang.

Dengan melihat banyaknya jumlah konsumen serta keberadaan pasar yang sangat penting pada pasar ini dan perkembangan yang baik serta berada dalam Kecamatan dengan volume pembeli yang cukup ramai. Penulis tertarik untuk mengkaji dan mengetahui apakah faktor yang menjadi alasan pembeli dalam pemilihan pasar Bandar Buat untuk pemenuhan kebutuhannya.

Karena keberadaan pasar yang sangat penting, penulis semakin tertarik untuk mengetahui wilayah cakupan pelayanan yang akan ditimbulkan oleh pasar tersebut yaitu Pasar Bandar Buat 
Kecamatan Lubuk Kilangan Kota Padang.

\section{METODE PENELITIAN}

\section{Jenis Penelitian}

Penelitian ini tergolong penelitian Deskriptif dengan menggunakan pendekatan kuantitatif, yaitu berusaha mengungkapkan wilayah cakupan pelayanan pasar Bandar Buat Kecamatan Lubuk Kilangan Kota Padang serta dilihat dari faktor yang mempengaruhi pengunjung pasar yaitu dari faktor aksesibilitas dan jarak.

\section{Populasi dan Sampel}

Populasi penelitian yaitu jumlah kepala keluarga yang ada pada tiga kecamatan yang berkunjung ke Pasar Bandar Buat di Kecamatan Lubuk Kilangan Kota Padang. Adapun jumlah Rumah Tangga pada tiga kecamatan tersebut dapat dilihat melalui tabel 1 berikut ini:

Tabel 1 Jumlah Rumah Tangga Pada Tiga Kecamatan

\begin{tabular}{llcl}
\hline No & $\begin{array}{l}\text { Nama } \\
\text { Kecamatan }\end{array}$ & $\begin{array}{l}\text { Jumlah } \\
\text { Rumah } \\
\text { Tangga }\end{array}$ & Jumlah \\
\hline 1 & Pauh & 14.406 & 14.40 \\
& & 6 \\
\hline 2 & Kuranji & 30.135 & 30.13 \\
& & 5 \\
\hline 3 & Lubuk & 11.034 & 11.03 \\
& Kilangan & & 4 \\
\hline & Total & 55.575 & 55.57 \\
& & & 5 \\
\hline
\end{tabular}

Sumber: BPS tahun 2010
Dalam penelitian ini, penentuan jumlah sampel ditentukan dengan menggunakan rumus berikut (Nazir, 2003) responden terbagi dalam tiga populasi yang dibagi menurut kesamaan yang dimiliki populasi. Ketiga populasi tersebut adalah: pengunjung pasar yakni masyarakat yang berada dalam wilayah pelayanan Pasar Bandar Buat yang mencakup tiga kecamatan, yaitu Kecamatan Pauh, Kecamatan Lubuk Kilangan, dan Kecamatan Kuranji. Jumlah kepala keluarga adalah sebanyak 55.575 KK (kondisi 2010).

Besarnya jumlah sampel untuk setiap populasi dihitung dengan cara menetapkan proporsi penelitian (p) sebesar 0,5 dan bound of error (B) ditetapkan 0,10. Penentuan jumlah sampel untuk masing-masing populasi, yaitu untuk pengunjung pasar

$$
n=\frac{55.575 \times 0.5(1-0.5)}{(55.575-1) 0.0025+0.5(1-0.5)}=99,8
$$

Dari perhitungan jumlah sampel tersebut di atas, sampel yang diperlukan yaitu sebanyak 100 orang pengunjung pasar.

\section{Alat Pengumpul Data \\ Untuk lebih jelasnya mengenai alat pengumpul data, dapat dilihat melalui tabel 2 di bawah ini:}


Tabel 2. Alat Pengumpulan Data

\begin{tabular}{|c|c|c|c|c|c|c|c|}
\hline \multirow[t]{3}{*}{ No } & \multirow[t]{3}{*}{ Tujuan Penelitian } & \multirow{3}{*}{$\begin{array}{l}\text { Data yang } \\
\text { Dibutuhkan }\end{array}$} & \multicolumn{3}{|c|}{$\begin{array}{c}\text { Alat } \\
\text { Pengumpul } \\
\text { Data } \\
\end{array}$} & \multicolumn{2}{|c|}{ Sumber Data } \\
\hline & & & \multicolumn{2}{|c|}{ Primer } & $\mathbf{S}$ & \multirow{2}{*}{ Primer } & \multirow{2}{*}{ Sekunder } \\
\hline & & & $\mathbf{O}$ & $\mathbf{W}$ & I & & \\
\hline 1. & $\begin{array}{lr}\text { Faktor-faktor yang } \\
\text { mempengaruhi } \\
\text { konsumen datang } \\
\text { berbelanja ke Pasar } \\
\text { Bandar } \\
\text { Kecamatan } & \text { Lubuat } \\
\text { Kilangan } & \text { Kota } \\
\text { Padang }\end{array}$ & $\begin{array}{l}\text { Aksesibilitas dan } \\
\text { jarak, jenis } \\
\text { barang, harga } \\
\text { barang, } \\
\text { kelengkapan } \\
\text { barang, } \\
\text { barang }\end{array}$ & $\sqrt{ }$ & $\sqrt{ }$ & $\sqrt{ }$ & $\begin{array}{l}\text { Pedagang, } \\
\text { Pembeli }\end{array}$ & $\begin{array}{l}\text { BPS } \\
\text { Dinas } \\
\text { Perhubungan }\end{array}$ \\
\hline 2. & $\begin{array}{lr}\text { wilayah pelayanan } \\
\text { Pasar Bandar Buat } \\
\text { Kecamatan } & \text { Lubuk } \\
\text { Kilangan } & \text { Kota } \\
\text { Padang } & \end{array}$ & $\begin{array}{l}\text { Faktor-faktor } \\
\text { yang } \\
\text { mempengaruhi }\end{array}$ & $\sqrt{ }$ & $\sqrt{ }$ & $\sqrt{ }$ & $\begin{array}{l}\text { Pedagang, } \\
\text { Pembeli }\end{array}$ & $\begin{array}{l}\text { Bappeda, Dinas } \\
\text { Perhubungan,D } \\
\text { inas Pasar }\end{array}$ \\
\hline
\end{tabular}

Teknik Analisis Data

\section{Menganalisis Wilayah Cakupan Pelayanan}

Menganalisis Wilayah Cakupan Pelayanan para pembeli di Pasar Bandar Buat Kecamatan Lubuk Kilangan Kota Padang maka digunakan analisis dengan menggunakan perangkat SIG melalui model Buffer. Dengan model buffer, maka akan terbentuk suatu area, poligon, atau zone baru yang menutupi atau melindungi objek spasial (buffered object) yang berupa objek-objek spasial titik, garis atau area, (poligon tertentu) dengan jarak tertentu (Prahasta, 2002).

\section{Menganalisis Faktor-faktor yang mempengaruhi pembeli memilih pasar Bandar Buat}

Menganalisis faktor pengunjung berdasarkan angket Perhitungan yang digunakan yaitu dengan teknik prosentase dilakukan dengan rumus:

$$
P=f / N \times 100
$$

Keterangan:

$$
\mathrm{P}=\text { Tingkat prosentase jawaban }
$$$$
\mathrm{F}=\text { Frekuensi jawaban }
$$$$
\mathrm{N} \text { = Jumlah sampel }
$$

Sedangkan data yang diperoleh melalui instrumen observasi dan wawancara akan dideskripsikan sesuai dengan kondisi temuan yang ada di lapangan

\section{HASIL DAN PEMBAHASAN}

Data hasil penelitian yang telah penulis lakukan di wilayah studi dengan 
daerah penelitian adalah Pasar Bandar Buat Kecamatan Lubuk Kilangan, dimana subjek penelitian adalah pembeli yang datang secara rutin ke masing-masing pasar. Berdasarkan data yang penulis kumpulkan baik berdasarkan hasil sebaran angket, wawancara, observasi ataupun data-data yang diperoleh dari dinas atau instansi terkait, maka hasil analisis mengenai pertanyaan penelitian pada pokok bahasan sebelumnya akan penulis bahas lebih lanjut dalam bentuk uraian berikut.

\section{Wilayah Cakupan Pelayanan Pasar Bandar Buat}

Hasil penelitian yang peneliti lakukan di Pasar Bandar Buat diketahui bahwa wilayah cakupan pelayanan Pasar Bandar Buat tersebar pada tiga kecamatan yaitu Kecamatan Lubuk Kilangan dengan persentase sebanyak $85 \%$, Kecamatan Pauh 10\%, dan Kecamatan Kuranji sebanyak 5\%. Pada Kecamatan Lubuk Kilangan, daerah cakupan pelayanan pembeli tersebar pada tujuh kelurahan, yaitu dengan persentase sebanyak $6 \%$ dari kelurahan Tarantang, sebanyak 9\% dari kelurahan Beringin, sebanyak 15\% dari kelurahan
Bandar Buat, sebanyak 9\% dari kelurahan Batu Gadang, sebanyak 12\% dari kelurahan Indarung, sebanyak 18\% dari kelurahan Padang Besi, dan sebanyak $16 \%$ dari kelurahan Koto Lalang.

Untuk wilayah diluar kecamatan Lubuk Kilangan yang termasuk dalam responden peneliti yaitu sebanyak $10 \%$ dari kecamatan Pauh yang tersebar pada tiga kelurahan berbeda yakni $4 \%$ dari Kelurahan Piai Tangah, 4\% dari Kelurahan Limau Manis, dan 2\% dari Kelurahan Kapalo Koto, dan 5\% dari Kecamatan Kuranji dengan asal Ke 5\% nya berasal dari kelurahan Kuranji.

Wilayah cakupan pelayanan pembeli tersebar pada tiga kecamatan yaitu Kecamatan Lubuk Kilangan dimana Pasar Bandar Buat terdapat pada Kecamatan ini, Kecamatan Pauh Kecamatan yang berbatasan langsung dengan Kelurahan Bandar Buat, dan Kecamatan Kuranji yaitu Kecamatan yang berbatasan dengan Kecamatan Pauh juga termasuk dalam wilayah cakupan Pelayanan Pasar Bandar Buat. Untuk lebih jelasnya wilayah pelayanan dapat dilihat melalui Gambar 1, 2, dan 3 di bawah ini:

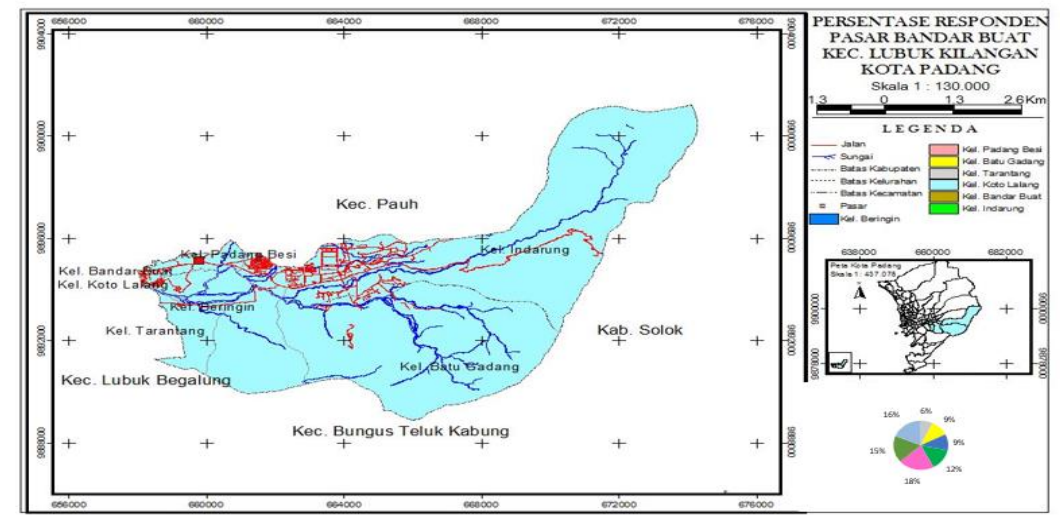

Gambar 1 Peta Persentase Responden 


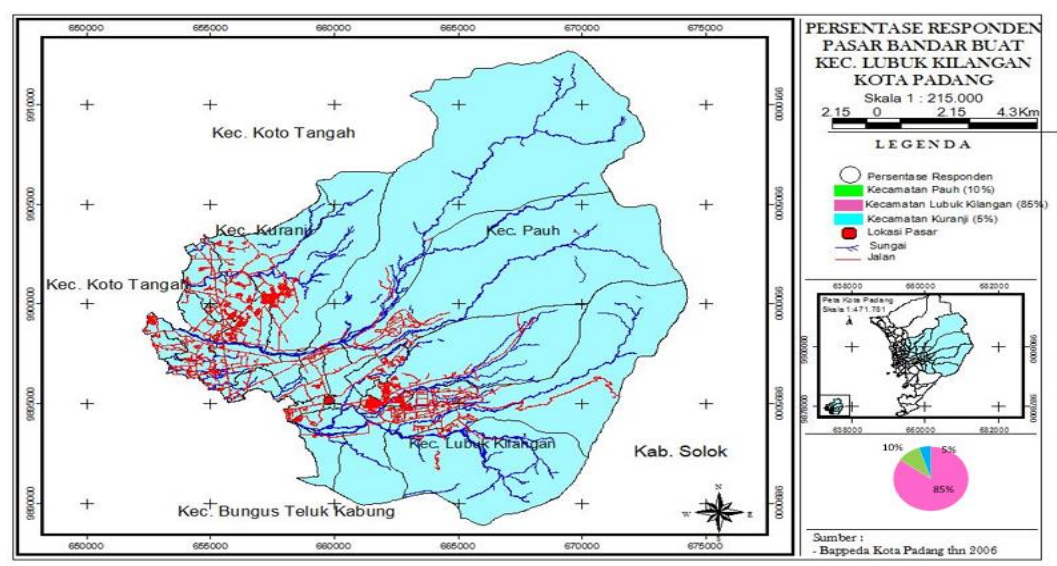

Gambar 2 Peta Persentase Responden

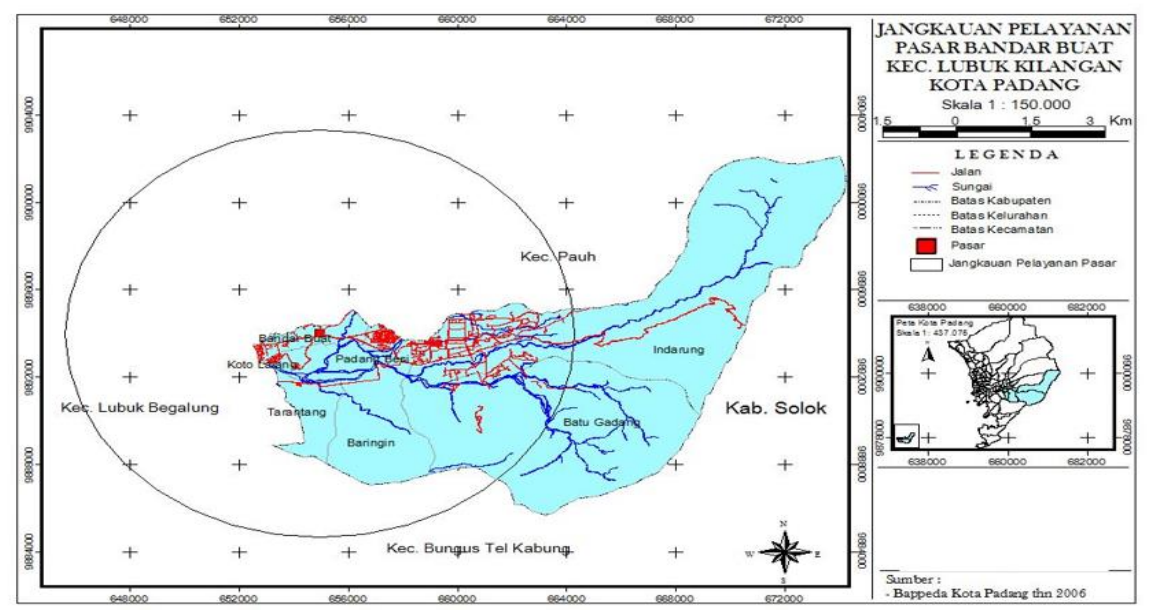

Gambar 3 Peta Jangkauan Pelayanan

Faktor-Faktor yang Mempengaruhi Pembeli Datang Berbelanja ke Pasar Bandar Buat Kota Padang

\section{Faktor Aksesibilitas dan Jarak}

Jaringan jalan dan layanan kemudahan untuk mencapai lokasi tujuan ditunjang dengan transportasi sebagai perwakilan aksesibilitas, sangat berpengaruh terhadap wilayah cakupan pelayanan dari sebuah pasar, jaringan jalan menuju Pasar Bandar Buat sudah baik dengan kondisi jalan yang sudah diaspal dan memiliki dua jalur dan kemudahan menjangkau pasar dari kawasan permukiman penduduk merupakan salah satu faktor yang mempengaruhi pembeli untuk datang berbelanja baik ke Pasar Bandar Buat. Begitu juga dengan layanan transportasinya, layanan transportasi menuju Pasar Bandar Buat mudah di dapatkan oleh masyarakat pengguna pasar.

Dengan banyaknya alat transportasi menuju masing-masing pasar ini membuat calon pembeli lebih mudah menjangkau pasar tujuannya. Transportasi yang melewati Pasar Bandar Buat terdiri dari berbagai jenis,baik berupa mikrolet ataupun jenis kendaraan umum roda dua seperti ojek. 
Jarak yang harus ditempuh masyarakat pengguna pasar atau pembeli menuju pasar akan mempengaruhi mereka untuk mengunjungi pasar tersebut. Artinya suatu pasar akan diminati oleh pembeli apabila pasar tersebut berjarak tidak terlalu jauh dari rumah mereka masingmasing.

Pembeli yang datang berbelanja ke Pasar Bandar Buat memberikan alasan jarak sebagai faktor yang mempengaruhi mereka untuk datang berbelanja. Dengan jarak (0,5-1Km) dengan waktu tempuh antara 5-10 menit tentu mereka lebih mudah untuk menjangkau pasar dengan pengunjung pasar yang berasal dari kelurahan Bandar Buat dan Koto Lalang. Jarak yang dekat juga memudahkan mereka untuk proses pengangkutan barangbarang belanjaan yang mereka beli di pasar ini.

Hal tersebut juga dibuktikan dengan banyaknya pembeli yang memberikan jawaban aksesibilitas dan jarak sebagai salah satu alasan mereka memilih Pasar Bandar Buat sebagai tempat membeli kebutuhan sehari-hari mereka. Jaringan jalan yang baik dan transportasi yang mudah di peroleh serta jarak yang relatif dekat membuat mereka tidak lagi melirik pasar lain untuk kegiatan rutin pemenuhan kebutuhan.

Artinya masyarakat menilai bahwa pasar yang memiliki kondisi jalan dan layanan transportasi yang baik cenderung lebih menarik untuk di kunjungi oleh masyarakat pembeli. Hal ini disebabkan karena adanya implikasi dalam kemudahan menjangkau pasar. Berdasarkan hasil penelitian yang telah penulis lakukan, pembeli mengemukakan bahwa aksesibilitas dan jarak sebagai salah satu alasan yang dikemukakan pembeli untuk berbelanja di Pasar Bandar Buat dengan skor 47, persentase sebesar $17 \%$.

\section{Faktor Jenis Barang}

Jenis barang merupakan sesuatu yang dapat ditawarkan ke pasaran atau konsumen untuk menarik perhatian. Jenis barang terdiri dari empat yang mana ada disebut dengan barang kebutuhan seehari-hari seperti teh, (gula, kopi, dan sejenisnya), barang tiga bulan sekali seperti (sendal, sepatu, dan barang peralatan sederhana lainnya), barang satu tahun sekali seperti (televisi, meja, kulkas, dan sebagainya), dan barang yang dibeli satu tahun sekali namun tergolong barang mewah seperti (emas). Berdasarkan hasil penelitian dilapangan yang peneliti lakukan di lapangan serta dari angket yang peneliti sebarkan bahwa jenis barang sebagai salah satu alasan pembeli memilih ke Pasar Bandar Buat dengan skor 50, persentase sebesar $18 \%$.

\section{Faktor Kualitas Barang}

Barang dengan kualitas yang baik merupakan hal yang paling utama di perhatikan oleh seorang konsumen pasar. Pembeli lebih mengutamakan kualitas barang sebagai hal yang menjadi acuan mereka untuk berbelanja. Pasar Bandar Buat berdasarkan hasil observasi yang peneliti lakukan, mampu memberikan hal tersebut kepada pelanggannya. Misalnya saja dilihat di Pasar Bandar Buat, penjual mendatangkan langsung jenis sayuran dan buah-buahan langsung dari daerah penghasi sayur-sayuran dan buaph-buahan seperti Solok, Padang Panjang, dan Muaro Labuh.

Hal tersebut di perkuat dengan alasan yang dikemukakan oleh pembeli tentang faktor yang mempengaruhi 
mereka untuk datang berbelanja ke Pasar Bandar Buat dengan skor 65, persentase sebesar $23 \%$.

\section{Faktor Kelengkapan Barang}

Pasar adalah salah satu wadah pemenuhan kebutuhan sehari-hari dari masyarakat pengguna pasar atau pembeli. Kelengkapan suatu pasar adalah hal yang sangat bergantung kepada kebutuhan dari si pembeli itu sendiri. Apabila barang-barang yang mereka butuhkan ada pada suatu pasar, maka mereka akan berasumsi bahwa pasar tersebut adalah lengkap, berbeda dengan pembeli yang tidak menemukan apa yang ia cari di suatu pasar, maka hal yang akan mereka ungkapkan adalah pasar tersebut tidak lengkap.

Dalam kajian penelitian ini, kelengkapan barang maksudnya adalah tersedia atau tidaknya barang yang pembeli butuhkan dari sebuah pasar. Banyak pembeli yang mengungkapkan bahwa Pasar Bandar Buat mampu melengkapi kebutuhan harian mereka. Lengkap adalah kata utama yang mereka ungkapkan ketika di tanya tentang alasan mereka memilih Pasar Pasar Bandar Buat sebagai pasar rutin pemenuhan kebutuhan mereka. Dari penelitian yang dilakukan, pembeli rutin di Pasar Bandar Buat mengungkapkan bahwa kelengkapan barang sebagai faktor yang mempengaruhi mereka untuk memilih Pasar Pasar Bandar Buat sebagai tempat berbelanja dengan skor 61 persentase sebesar $22 \%$.

\section{Harga}

Harga adalah hal yang paling utama dalam kegiatan jual beli di sebuah pasar, dimana pasar tradisional adalah suatu tempat yang didalamnya terjadi proses jual beli secara tawar menawar. Harga yang murah dengan kualitas yang baik sangat di sukai oleh pembeli di sebuah pasar tradisional. Keterjangkauan pembeli untuk membeli sesuatu juga berhubungan dengan harga yang ditawarkan oleh si penjual. Apabila harga yang ditawakan penjual sesuai dan sanggup di beli oleh si pembeli maka proses jual beli akan berlangsung dengan baik. Keputusan pembeli untuk membeli barang yang ditawakan penjual akan bergantung kepada kesepakatan harga tersebut.

Begitu juga dengan pembeli rutin yang datang ke Pasar Bandar Buat, harga adalah patokan penting mereka dalam pemilihan tempat berbelanja. Rata-rata pembeli rutin memberikan alasan harga sebagai faktor yang mempengaruhi mereka datang secara rutin berbelanja baik ke Pasar Bandar Buat. Berdasarkan hasil penelitian di lapangan, penulis menemukan pembeli rutin mengungkapkan bahwa harga adalah salah satu faktor yang mempengaruhi mereka datang berbelanja ke pasar tersebut dengan skor 56 persentase sebesar $20 \%$.

Untuk lebih jelasnya mengenai keterkaitan faktor terhadap pembeli dapat dilihat melalui Tabel 3 dan grafik 1 berikut ini:

Tabel 3 Rekapitulasi Keterkaitan Faktor Terhadap Pembeli

\begin{tabular}{llll}
\hline No & Faktor & Skor & $(\%)$ \\
\hline 1 & Aksesibilitas dan Jarak & 47 & 17 \\
\hline 2 & Jenis Barang & 50 & 18 \\
\hline 3 & Kualitas & 65 & 23 \\
\hline 4 & Kelengkapan Barang & 61 & 22 \\
\hline 5 & Harga & 56 & 20 \\
\hline Jumlah & 279 & 100 \\
\hline Sumber: Analisis Data 2012 & &
\end{tabular}

Sumber: Analisis Data 2012 


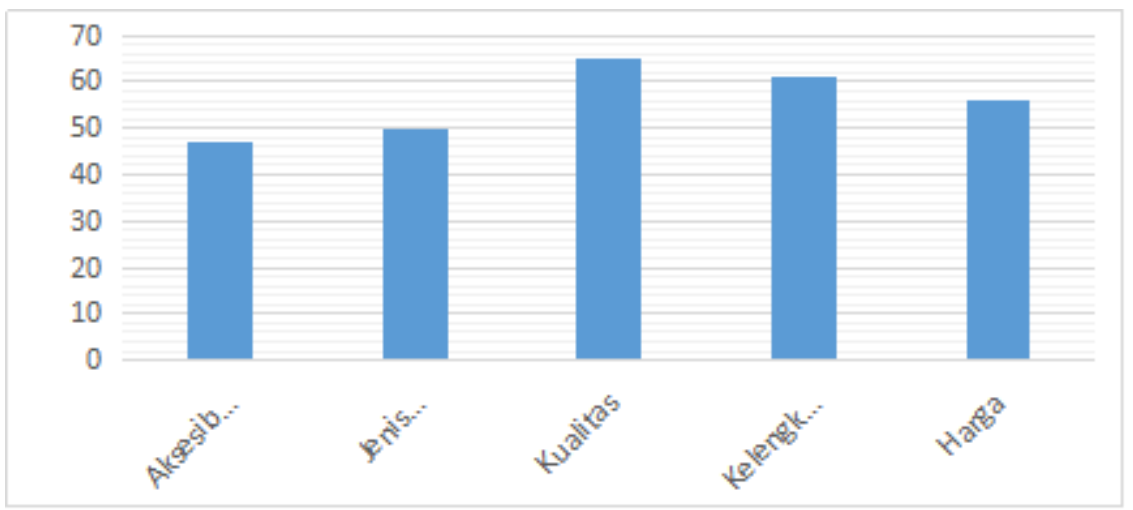

Gambar 2 Rekapitulasi Data Keterkaitan Faktor Terhadap Pembeli

Berdasarkan grafik diatas dapat kita lihat bahwa faktor aksesibilitas dan jarak memiliki skor 47 dengan persentase $17 \%$, faktor jenis barang memiliki skor 50 dengan persentase $18 \%$, faktor kualitas memiliki skor 65 dengan persentase $23 \%$, faktor kelengkapan barang memiliki skor 61 dengan persentase $22 \%$, dan faktor harga memiliki nilai 56 dengan persentase $20 \%$.

\section{Penggunaan Teori Lokasi Terhadap Posisi Pasar Bandar Buat}

Pasar Bandar Buat terletak pada Kecamatan Lubuk Kilangan. Kecamatan Lubuk Kilangan dalam beberapa tahun terakhir juga merupakan daerah penghasil tanaman pangan seperti padi. Sehingga Kecamatan Lubuk Kilangan merupakan salah satu dari berbagai kecamatan di Kota Padang yang merupakan daerah penghasil tanaman pangan yang berbatasan langsung dengan Kabupaten Solok.

Sedangkan Kabupaten Solok dan Muara Labuh merupakan daerah penghasil sayuran serta buah-buahan, Kabupaten Pesisir Selatan merupakan daerah penghasil ikan untuk Kota Padang. Pasar Bandar Buat menjadi tempat produktif untuk penjualan sayursayuran, buah-buahan serta ikan segar karena didatangkan langsung dari daerah Solok dan Pesisir Selatan sebagai penghasil sayur, buah-buahan dan ikan segar.

Aktivitas yang produktif yang terjadi pada Pasar Bandar Buat, sehingga langsung menjangkau para konsumennya tanpa harus mengeluarkan banyak biaya. Keberadaan para penjual yang datang dari daerah asalnya untuk menjual hasil produksinya secara langsung sehingga para pedagang dapat memperoleh keuntungan secara maksimal tanpa harus melalui perantara.

Teori Van Thunen, yakni membandingkan hubungan antara biaya produksi, harga pasar dan biaya transportasi. Kewajiban petani adalah memaksimalkan keuntungan yang didapat dari harga pasar dikurang biaya transportasi dan biaya produksi. Aktivitas yang paling produktif seperti berkebun dan produksi susu sapi, atau aktivitas yang memiliki biaya transportasi tinggi seperti kayu bakar, lokasinya dekat dengan pasar. Teori Von Thunen ini dapat digunakan sebagai dasar pendekatan 
pengembangan wilayah kawasan perbatasan, khususnya melalui pengembangan transportasi.

Berdasarkan keberadaan pusat kota yang lumayan jauh sehingga dengan keberadaan Pasar Bandar Buat dapat menekan biaya produksi serta biaya transportasi dengan memaksimalkan keuntungan para pedagang yang berasal dari luar kota khususnya para pedagang yang berasal dari Solok, MuaraLabuh, dan Pesisir Selatan dalam melakukan aktivitas perdagangan di Pasar Bandar Buat.

Sehingga keberadaan Pasar Bandar Buat dapat dikatakan mengikuti teori lokasi model Van Thunen, dimana kegiatan ekonomi komoditas yang paling efisien yakni meminimalkan biaya transportasi dan biaya produksi guna memaksimalkan keuntungan dengan keberadaan pasar yang dekat dengan bahan baku atau penyediaan barang serta jauh dari market (pusat kota).

\section{SIMPULAN}

Berdasarkan hasil penelitian dan pembahasan yang telah dikemukakan sebelumnya, dapat disimpulkan bahwa:

1. Wilayah Cakupan Pelayanan Pasar Bandar Buat berdasarkan hasil analisis data yang dilakukan yaitu tersebar di tujuh kelurahan yang ada di Pasar Bandar Buat dengan rincian, 6 orang dari kelurahan Tarantang, 9 orang dari Kelurahan Beringin, 15 orang dari Kelurahan Bandar Buat, 9 orang dari Kelurahan Batu Gadang, 12 orang dari Kelurahan Indarung, 18 orang dari Kelurahan Padang Besi, dan 16 orang dari Kelurahan Koto Lalang. Untuk wilayah diluar kecamatan Lubuk Kilangan yang termasuk dalam responden peneliti yaitu sebanyak 10 orang dari kecamatan Pauh yang tersebar pada tiga kelurahan berbeda yakni 4 orang dari Kelurahan Piai Tangah, 4 Orang dari Kelurahan Limau Manis, dan 2 orang dari Kelurahan Kapalo Koto, dan 5 orang dari Kecamatan Kuranji dengan asal kelurahan Kuranji.

2. Faktor-faktor yang mempengaruhi pembeli rutin datang berbelanja ke Pasar Bandar Buat adalah karena beberapa faktor, yaitu

a. Faktor Aksesibilitas dan jarak yang diwakili oleh jaringan jalan dan layanan transportasi serta kedekatan jarak dengan lokasi yang melewati pasar, jaringan jalan yang baik dan layanan transportasi yang mudah di jangkau akan memberikan nilai positif bagi suatu pasar. Hal ini disebabkan karena adanya implikasi dalam kemudahan menjangkau pasar. Responden memberikan jawaban bahwa faktor jarak dan Aksesibilitas mempengaruhi mereka datang berbelanja untuk Bandar Buat dengan skor 47 persentase sebesar $18 \%$.

b. Faktor Jenis Barang, yang kelengkapan jenis barang, mulai dari barang harian, perlengkapan sederhana, perlengkapan bulanan bahkan kebutuhan mewah, hal ini terbukti dengan pembeli rutin di Pasar Bandar Buat mengemukakan tentang jenis barang mempengaruhi mereka datang berbelanja ke Pasar Bandar Buat dengan skor 50 persentase sebesar $18 \%$.

c. Faktor Kualitas Barang, barang dengan kualitas yang baik 
merupakan hal yang paling utama di perhatikan oleh seorang konsumen pasar. Pembeli cenderung mengutamakan kualitas barang sebagai hal yang menjadi acuan mereka untuk berbelanja. Dimana pembeli rutin di Pasar Bandar Buat menyatakan bahwa faktor kualitas barang mempengaruhi mereka datang berbelanja ke masing-masing pasar dengan skor 65 persentase sebesar $23 \%$.

d. Faktor Kelengkapan Barang, maksudnya adalah tersedia atau tidaknya barang kebutuhan seharihari yang pembeli butuhkan dari sebuah pasar. untuk Pasar Bandar Buat pembeli rutin menjawab kelengkapan barang mempengaruhi mereka datang berbelanja ke pasar ini dengan skor 61 persentase sebesar $22 \%$.

e. Faktor Harga, hal yang paling utama dalam kegiatan jual beli di sebuah pasar, dimana pasar adalah suatu tempat yang didalamnya terjadi proses jual beli secara tawar menawar. Harga yang murah dengan kualitas yang baik sangat di sukai oleh pembeli di sebuah pasar tradisional. untuk Pasar Bandar Buat pembeli rutin mengungkapkan hal yang sama bahwa harga adalah alasan yang mempengaruhi mereka datang berbelanja ke Pasar Bandar Buat dengan skor 56 persentase sebesar $20 \%$.

\section{DAFTAR PUSTAKA}

Badan Pusat Statistik Kota Padang (2010). Lubuk Kilangan Dalam Angka 2010. BPS Kota Padang. Padang

Badan Pusat Statistik Kota Padang (2010). Kuranji Dalam Angka 2010. BPS Kota Padang. Padang

Badan Pusat Statistik Kota Padang (2010). Pauh Dalam Angka 2010. BPS Kota Padang. Padang

Nazir, M. (2003). Metode Penelitian. Jakarta: Ghalia Indonesia.

Nia. (2010). Pengertian Pasar Tradisional dan Pasar Modern. (Online),(http://niaas8.wordpress. com/, diakses 29 Oktober 2011)

Oktaria, R. (2011). Wilayah Pengaruh Pasar Simpang Tabing Dan Pasar Lubuk Buaya Kecamatan Koto Tangah Kota Padang. Laporan penelitian tidak diterbitkan. Padang: FIS UNP.

Prahasta, E. (2002). Konsep-konsep Dasar sistem Informasi Geografis. Bandung: Informatika

Umar, H. (2003). Business An Introduction. Jakarta : PT SUN 